\title{
German Romanticism and Liturgical Theology: Exploring the Potential of Organic Thinking
}

\author{
JORIS GELDHOF \\ Katholieke Universiteit Leuven
}

There is significant correspondence between two phenomena that are very rarely treated together yet reveal intriguing similarities: liturgical theology and German Romanticism. The key shared concept is "organism," a category expressing active life as well as coherence. It shows a way out of the deadlock caused by a simple opposition of objectivism and subjectivism. This article first of all presents an interesting kind of liturgical theology that was done by representatives of the Catholic Tübingen School, and then shows that the emerging Liturgical Movement was intrinsically Romantic in its theological approach to the liturgy.

Keywords: German Romanticism, liturgical theology, organism, Catholic Tübingen School, Liturgical Movement, Lambert Beauduin, Romano Guardini, Pius Parsch

$\mathrm{T}$

HE hypothesis underlying the present article is that it is intriguing, meaningful, and important to integrate two worlds of thought that, to the best of my knowledge, have so far been only rarely compared: German Romanticism and liturgical theology. Nevertheless, there are both historical and systematic-theological reasons to attempt such an exercise. One could definitely defend the idea that there was some sort of liturgical theology among German intellectuals in the first half of the nineteenth century,

Joris Geldhof is Professor of Liturgical Studies and Sacramental Theology at the Faculty of Theology and Religious Studies of the Catholic University of Leuven, Belgium. He chairs the local Liturgical Institute and is editor in chief of the bilingual journal Questions Liturgiques/Studies in Liturgy. Major publications include the edited volumes Mediating Mysteries, Understanding Liturgies: On Bridging the Gap between Liturgy and Systematic Theology (Leuven: Peeters, 2015) and, with Marianne Moyaert, Ritual Participation and Interreligious Dialogue: Boundaries, Transgressions, and Innovations (New York: Bloomsbury, 2015). He was elected president of Societas Liturgica in 2015 for a two-year term. 
in particular among the Catholic Tübingen School. ${ }^{1}$ One could also make a case for strong thematic parallels between the two. Nevertheless, it is difficult, if not impossible, to postulate a direct influence of Romanticism on the Liturgical Movement or, conversely, an explicit dependence of twentiethcentury liturgical theology upon nineteenth-century Romantic thought. ${ }^{2}$ Therefore, the goal of this article is not to demonstrate any lineage on the basis of detailed textual analyses and investigations of the sources of individual thinkers. Rather, I want to explore the profundity and expressiveness of theological correspondences between German Romanticism and liturgical theology and develop an argument in support of liturgical theology's robust reality claims. Hence the focus is more on contributing to contemporary liturgical-theological thinking than to the historiography of theology.

The guiding concern of the present reflection is to determine what resources nineteenth-century Romantic thought offers for developing (an) unadulterated liturgical theology today, whereby liturgical theology is defined as the study of the meaning of Christian worshiping practices and rituals and, more precisely, as the attempt to theologize from and on the basis of (actually existing) liturgies. ${ }^{3}$ Consequently, the method employed in this article is neither purely descriptive nor analytical. Rather, this exercise of thought draws on the history of ideas, philosophy, and theology alike, and aims at a constructive synthesis as well as a more nuanced understanding of the intrinsic potential of liturgical theology if done in a Romantic fashion.

I have adopted a fivefold structure. First, I start in the history of theology and demonstrate that there were Romantic theologians who gave worship, cult, or sacraments a genuine place in their theological syntheses. These theologians must be situated against the background of what has become known generally as the Catholic Tübingen School, ${ }^{4}$ over which Friedrich Schelling especially exerted a considerable influence. ${ }^{5}$ Second, I try to define what was typical of Romantic theological thinking. I will do that in dialogue with

${ }^{1}$ Samuel Goyvaerts, "A Romantic Theology of the Eucharist: The Catholic Tübingen School and the Communal Celebration of the Eucharist," Ephemerides Liturgicae 127 (2013): 60-84.

${ }^{2}$ Thomas F. O'Meara, "The Origins of the Liturgical Movement and German Romanticism," Worship 59 (1985): 326-42.

${ }^{3}$ David W. Fagerberg, Theologia Prima: What Is Liturgical Theology? (Chicago: Hillenbrand Books, 2003).

4 The most encompassing study on this peculiar theological school is still Josef Rupert Geiselmann, Die katholische Tübinger Schule: Ihre theologische Eigenart (Freiburg: Herder, 1964). For a contemporary survey in English, see Bradford E. Hinze, "Roman Catholic Theology: Tübingen," in The Blackwell Companion to Nineteenth-Century Theology, ed. David Fergusson (Malden, MA: Wiley-Blackwell, 2010), 187-213.

5 Thomas F. O'Meara, German Idealism and Roman Catholicism: Schelling and the Theologians (Notre Dame, IN: University of Notre Dame Press, 1982). 
prominent interpreters of the German Romantic movement. Third, I argue that this Romantic thought focuses above all on the concept or the metaphor of organism, and I apply this insight to the thinkers' dealings with liturgy and sacraments. Fourth, I discuss the richness of the organic metaphor in the work of a selection of famous liturgical theologians of the early twentieth century (I obviously have to limit myself more than I would prefer). The central question for this discussion is whether, and to which extent, their use of organic modes of thinking can be rightly called Romantic. Fifth and finally, I indicate some avenues for further reflection and research. In what sense and why is it meaningful to pursue the connection between German Romanticism and liturgical theology today?

\section{Liturgical Theology in the Catholic Tübingen School}

It is important to stress that the history of Catholic theology between the Council of Trent and the twentieth century is not merely one of rigidity, obedience to ecclesial authority, a lack of creativity, or a culture of oppression and control, essentialism and scholasticism, as a widespread bias might hold. ${ }^{6}$ Among other contexts, southern Germany in the first half of the nineteenth century appeared to be particularly fruitful for the development and stimulation of authentic theological thinking. In the history of culture, this period is widely known as the era of Romanticism. Romanticism, however, is much more than a categorization of a bygone mentality or epoch; it has a significant philosophical pertinence, ${ }^{7}$ especially when dealing with religion. ${ }^{8}$ So one could definitely make the case that Romanticism is pertinent for theology as well.

The Romantic mind-set deeply impacted the representatives of the socalled Tübingen School. Their attempts to theologize in a scientific way-in continuous dialogue with contemporary critical consciousness, and with

${ }^{6}$ With respect to the theology of the Eucharist, a particular problem was related to a narrow understanding of sacrifice. For some background, see Robert J. Daly, "Bellarmine and Post-Tridentine Eucharistic Theology," in From Trent to Vatican II: Historical and Theological Investigations, ed. Raymond F. Bulman and Frederick J. Parrella (Oxford: Oxford University Press, 2006), 81-101. Cf. also Trent Pomplun, "Post-Tridentine Sacramental Theology," in The Oxford Handbook of Sacramental Theology, ed. Hans Boersma and Matthew Levering (Oxford: Oxford University Press, 2015), 348-61, where one can read a discussion about Daly's findings.

7 This is convincingly demonstrated in Nicholas Kompridis, ed., Philosophical Romanticism (London and New York: Routledge, 2006).

${ }^{8}$ Douglas Hedley, Living Forms of the Imagination (London and New York: T\&T Clark, 2008). 
due respect for the church, its tradition, and its institutions-constitute a unique model for theology. ${ }^{9}$ This threefold characterization, though general, is definitely accurate and can serve as a paradigm for much contemporary theologizing. One of its advantages is that it attempts to mediate among three poles instead of only two. Tübingen theology attempts to excel in scientific character, to be faithful to the tradition of the church, and to be in a continuous dialogue with the surrounding context-and to do all that simultaneously, that is, without altering the fundamental discourse in view of the audience or the situation, and without making (too many) compromises for one or another extrinsic reason.

In a certain sense ahead of its time, the Catholic Tübingen School made a case for the sacramentality of the church, ${ }^{10}$ advocated the historicity of dogma (prior to and contemporaneous with Newman), promoted a dynamic understanding of revelation that did not focus solely on the epistemic truth of propositions, and showed a renewed interest in the relation between faith and reason. Its merits are numerous, as some famous scholars of the movement (e.g., Walter Kasper) have pointed out convincingly, even if there is a disproportion in terms of its recognition. It would not be a mistake to contend that their contributions to the church's ongoing theological wisdom were only realized and acknowledged at Vatican II, and that the Catholic Tübingen theologians have been true "precursors" or "pioneers" of contemporary theological thinking (Wegbereiter heutiger Theologie), as a German series with introductions and fine selections of primary texts accurately expresses it.

In addition to the above-mentioned insights, which in the meantime may have become widespread (if not evident) in theological circles, one could defend the idea that the innovative character of the Tübingen School in ecclesiology and fundamental theology could be extended to the field of liturgy and sacraments. Three examples may suffice. ${ }^{11}$

9 These are the three foundational characteristics of the school, as has been shown by Max Seckler. More recently, Stephan Warthmann vigorously defended Seckler's thesis over against rejections of the idea that there has ever been a theological "school" related to the Faculty of (Catholic) Theology in Tübingen. See Max Seckler, "Weltoffene Katholizität: Die Idee des Wilhelmsstifts Tübingen in Geschichte und Gegenwart," Theologische Quartalschrift 162 (1982): 178-202; Stephan Warthmann, Die katholische Tübinger Schule: Zur Geschichte ihrer Wahrnehmung (Stuttgart: Steiner, 2011).

${ }^{10}$ Jean-Marie Pasquier, L'Église comme sacrement: Le développement de l'idée sacramentelle de l'Église de Moehler à Vatican II (Fribourg: Academic Press, 2008); Michael J. Himes, Ongoing Incarnation: Johann Adam Möhler and the Beginnings of Modern Ecclesiology (New York: Crossroad, 1997).

${ }^{11}$ Although they could and perhaps should be included, I do not mention the works of Johann Adam Möhler (1796-1838) and Johann Evangelist Kuhn (1806-87). For a relevant article on Möhler and liturgy (but, as usual in Möhler studies, with a strong emphasis on 
First of all, reference must be made to the "founder" or the "father" of the school, Johann Sebastian Drey (1777-1853), who was deeply involved in the organization of the teaching programs of the newly established theological faculty at Tübingen. In 1819 he published his Kurze Einleitung in das Studium der Theologie, ${ }^{12}$ in which traces of Schleiermacher's 1811 Kurze Darstellung des theologischen Studiums can clearly be observed. ${ }^{13}$ Interestingly, Drey goes beyond a common illustrative approach to liturgy, according to which theologians (especially dogmaticians) freely use the liturgy (especially its euchology) as a resource for examples. Instead of such a noncommittal strategy, Drey allots the liturgy a constitutive role. Next to doctrine (Lehre) and discipline (Verfassung), cult (Kult) is, according to him, one of the three shapes in and through which the church expresses and communicates its essence. All three are directly connected to Jesus Christ, the incarnate Son of God, and his three munera of prophet, king, and priest. Therefore, cult, or liturgy, has an intrinsic relation to theology, instead of a merely external one. This fundamental insight makes it possible for the liturgy to be considered no longer as a repertoire of illustrations but as a locus theologicus in its own right. $^{14}$

Second, it is important to refer to the moral and pastoral theologian Johann Baptist Hirscher (1788-1865). Hirscher was the author of major works in the field of catechetics and Christian ethics, ${ }^{15}$ and counts as someone in whom the ideals of the Enlightenment found an effective continuation. The Eucharist was also definitely one of his major concerns. ${ }^{16}$

ecclesiology), see R. William Franklin, "Johann Adam Möhler and Worship in a Totalitarian Society," Worship 67 (1993): 2-17.

12 Johann Sebastian Drey, Kurze Einleitung in das Studium der Theologie mit Rücksicht auf den wissenschaftlichen Standpunct und das katholische System, ed. Max Seckler (Tübingen: Francke, 2007).

${ }^{13}$ For an English edition of this work, see Friedrich D. E. Schleiermacher, Brief Outline of Theology as a Field of Study: Revised Translation of the 1811 and 1830 Editions, trans. and ed. Terrence N. Tice, 3rd ed. (Louisville, KY: Westminster John Knox Press, 2011).

${ }^{14}$ For a detailed discussion about the concept of liturgy as locus theologicus, see Julia Knop, Ecclesia orans: Liturgie als Herausforderung für die Dogmatik (Freiburg im Breisgau: Herder, 2012).

${ }^{15}$ Johann Baptist Hirscher, Katechetik oder der Beruf des Seelsorgers, die ihm anvertraute Jugend im Christenthum zu unterrichten und $z u$ erziehen, nach seinem ganzen Umfange dargestellt (Tübingen: Laupp, 1834); Hirscher, Die christliche Moral als Lehre von der Verwirklichung des göttlichen Reiches in der Menschheit, 5th ed., 3 vols. (Tübingen: Laupp, 1851).

${ }^{16}$ See, e.g., one of his earlier works: Johann Baptist Hirscher, Missae genuinam notionem eruere ejusque celebrandae rectam methodum monstrare tentavit (Tübingen: Laupp, 1821). 
According to Hirscher, the Eucharist was not only the subject of lively debates between Protestants and Catholics as well as among Catholics themselves, but also a ritual and an outstandingly communal celebration. When dealing with the Eucharist, he clearly looked beyond the confines of dogmatic principles, speculative ideas, and magisterial decisions. This may be clearly seen in (1) his emphasis on the act of communion as a worthy reception of the Body of Christ, (2) his rejection of the practice whereby more than one Mass was being celebrated at the same time in one church, (3) his passionate plea for the vernacular, (4) his insistence on the (ongoing) formation of both clergy and laypersons, and (5) the idea that the Eucharist participates in the establishment of God's kingdom.

Third, one must remember the fascinating figure of Franz Anton Staudenmaier (1800-1856), one of the first sincere (and severe) theological critics of Hegel, ${ }^{17}$ thereby anticipating most of what has been said about Hegel in the course of the twentieth century. ${ }^{18}$ Basically, Staudenmaier demonstrated that any logic of Aufhebung will never be able to grasp what Erlösung really is; Hegel's system simply cannot capture the mystery of redemption, because it fails to imagine why a redeeming activity from outside the system would be necessary and how it could be operative and effective. Soteriology was indeed paramount in Staudenmaier's theological system as it is densely outlined in his Encyclopädie. ${ }^{19}$ This soteriological dimension at once explains the reasons why the history of salvation is the true principle of his interpretations of the Eucharist as well as the liturgical year. In his best-received work, Der Geist des Christenthums, ${ }^{20}$ the liturgy plays a constitutive role; it is a natural and integral part of his theological synthesis. It will come as no surprise, then, that Staudenmaier's work exerted a considerable influence on the authors who drafted the first manuals of liturgical studies. ${ }^{21}$ According to Staudenmaier, the Eucharist is the concrete event where the reconciliation and reunification of God with humanity take

${ }^{17}$ Franz Anton Staudenmaier, Darstellung und Kritik des Hegelschen Systems: Aus dem Standpuncte der christlichen Philosophie (Mainz: Florian Kupferberg, 1844).

18 See, e.g., Cyril O’Regan, The Heterodox Hegel (Albany: State University of New York Press, 1994); William Desmond, Hegel's God: A Counterfeit Double? (Aldershot, UK: Ashgate, 2003).

19 Franz Anton Staudenmaier, Encyclopädie der theologischen Wissenschaften als System der gesammten Theologie, 2nd ed. (1834; Mainz: Florian Kupferberg, 1840).

${ }^{20}$ Franz Anton Staudenmaier, Der Geist des Christenthums dargestellt in den heiligen Zeiten, in den heiligen Handlungen und in der heiligen Kunst, 2nd ed., 2 vols. (Mainz: Florian Kupferberg, 1838).

${ }^{21}$ Heinrich Plock, Feier der Versöhnung und des göttlichen Lebens: Zur Theologie der Liturgie und ihrer heilsgeschichtlichen Begründung im Systemdenken Franz Anton Staudenmaiers (Münster: Aschendorff, 1978). 
place: the worshiper, or celebrant, actually enters into the Trinitarian mystery and takes part in Jesus Christ's sacrifice.

Clearly, for all these authors, liturgy and Eucharist were realities reaching far beyond the scope of rubricism. The genius of their thinking entailed, however, not simply a critique of a rigid juridical and theological approach to the sacraments, but consisted in a genuine rediscovery of the depths and the riches of the Christian "cult." There is no doubt that they anticipated much of what was to become typical of the Liturgical Movement and its theological interpretation of Christian rituals and worship. Before we draw that parallel in greater detail, however, it is necessary to demonstrate in what sense their thinking is, also unmistakably, utterly Romantic.

\section{A Brief Sketch of Romantic Thinking: Organism}

A good place to start a discussion of the particularity of Romantic thinking is the following quotation from Friedrich Schlegel (1772-1829), doubtlessly one of the most prominent figures of the German Romantic movement: "True philosophy can nowhere fix a persistent substance, something which simply rests or is unchangeable. It finds the highest reality only in an eternal becoming, an eternally living activity, which, under constantly varying forms and shapes, generates out of itself a countless fullness and multiplicity." 22 What strikes one more than anything else in this quotation is the emphasis on liveliness. True philosophy, says Schlegel, does not determine things and does not even deal with anything unchanging or unvarying. Rather, reality is interpreted in a constant flux and as an unremittingly moving action.

Apparently, it is typical of Romantic thinking to use the model of life to explain and understand everything: "Thus, the Romantic philosophy of nature, as well as Romantic philosophy as such, is a philosophy of life."23 Or, as Schelling, often considered to be "the Romantic philosopher par excel-

22 "Die wahre Philosophie kann nirgends eine beharrliche Substanz, ein Ruhendes, Unveränderliches statuieren, sie findet die höchste Realität nur in einem ewigen Werden, einer ewig lebendig beweglichen Tätigkeit, die unter stets wechselnden Formen und Gestalten eine unendliche Fülle und Mannigfaltigkeit aus sich erzeugt." Quoted in Paul Kluckhohn, Das Ideengut der deutschen Romantik, 5th ed. (Tübingen: Max Niemeyer, 1966), 15. Unless otherwise noted, all translations from German into English throughout this article are my own. The original texts are always cited in the footnotes.

${ }^{23}$ Kluckhohn, Das Ideengut, 31: "So ist romantische Naturphilosophie wie romantische Philosophie überhaupt Philosophie des Lebens." 
lence," ${ }^{24}$ puts it, "What everyone is justified in expecting from philosophy, is a science that is able to cope with life and that, for that very reason, instead of turning pale before the enormous reality of life, increases in strength and power as life experiences continue. The youth desire truth, an ultimate, lifeguiding truth." 25

In other words, any philosophy-or, more generally, any attempt at understanding - should correspond to life; and truth is above all something to live from, rather than a set of principles and convictions. ${ }^{26}$ Truth is and must be something concrete, that is, something that has "grown together" with something instead of having been "torn away" from it. ${ }^{27}$

Another central feature of Romantic thinking is its pursuit of coherence and its desire for systematicity. Romantics see connections everywhere and strive to interpret them within larger frameworks or networks. As Louis Dupré observes, the "true originality" of the Romantics consists in their conviction "that a more fundamental exploration of the grounding subject would lead to a groundless absolute, in which the opposition between mind and reality would cease to exist," ${ }^{28}$ whereby they deliberately attempted "to break through the limits of finitude, the objective as well as the subjective, toward an all-inclusive absolute." 29

${ }^{24}$ Louis Dupré, The Quest of the Absolute: Birth and Decline of European Romanticism (Notre Dame, IN: University of Notre Dame Press, 2013), 18; see also 294: "Schelling was the philosopher of Romanticism. His thought gave philosophical support to the aspirations of the Romantic Movement in Germany. The ontological significance that he ascribed to the aesthetic intuition, his symbolic interpretation of nature, and the particular emphasis he placed on freedom made his entire philosophy an integral part of the Romantic quest of the absolute. Later generations have neglected him, possibly because his thought was closely linked to Fichte's Idealism. Yet he was the philosophical genius among the idealists and the most original Romantic thinker."

${ }^{25}$ Friedrich Wilhelm Joseph Schelling, Grundlegung der positiven Philosophie: Münchner Vorlesung WS 1832/33 und SS 1833, ed. Horst Fuhrmans (Turin: Bottega d'Erasmo, 1972), 69: "Was jeder von der Philosophie zu erwarten berechtigt ist, ist eine Wissenschaft, die dem Leben gewachsen ist, die eben darum, weit entfernt vor der ungeheuren Realität des Lebens zu erblassen, mit der fortschreitenden Lebenserfahrung selbst nur an Stärke und Kraft gewinnt. Wahrheit, eine letzte, das Leben leitende Wahrheit, verlangt die Jugend."

${ }^{26}$ Joris Geldhof, “'Truth' According to the Later Schelling and Baader: An Attempt at Transcending Modernity," in Theology and the Quest for Truth: Historical- and Systematic-Theological Studies, ed. Mathijs Lamberigts, Lieven Boeve, and Terrence Merrigan (Leuven and Dudley, MA: Peeters, 2006), 107-18.

${ }^{27}$ An allusion is made here to the etymological origin of the words "concrete" and "abstract," namely, the Latin verbs concrescere and abstrahere.

${ }^{28}$ Dupré, The Quest of the Absolute, 338.

29 Ibid., 339. 
These connections, correlations, combinations, and correspondences are never purely fragmentary or coincidental but always make sense within a system. Schelling continues in the passage quoted above:

This time desires truth, nothing but truth.... However, there is no such thing as an individual or isolated truth. For, everything is so wonderfully concatenated, that it is simply impossible to show any object in full separation from other objects.... Thus, philosophy is the attempt at knowledge of the general coherence, and, according to its very nature, it necessarily strives after system, so that the goal can only be reached in the systemin the general system, to be precise. ${ }^{30}$

Since there is no isolated truth, philosophy must seek the coherence of all things and cannot but be systematic: "Therefore, philosophy is essentially system. For nothing is true of itself, rather everything only in connection with the whole." 31

Paul Kluckhohn argues that these two fundamental dimensions, the attempt to develop a philosophy of life ("Hinzielen auf eine Philosophie des Lebens") and the striving after synthesis ("Synthesestreben"), have permeated all of the different phases of the Romantic movement. ${ }^{32}$ Here lies, moreover, the reason why there is an emphatic correspondence between German Romanticism and the idealism of the great system-builders:

There can be no doubt that a genuine affinity existed between the Romantics and the great speculative systems of their time. For what lay behind these systems was a certain disposition of mind, a desire to compass life as a whole. To the idealist philosophers as to the Romantics all experience entered into their purview; nothing was irrelevant, and the life of thought and imagination was no less real than that of the body

${ }^{30}$ Schelling, Grundlegung, 70: "Nach Wahrheit verlangt diese Zeit, nach nichts als nach Wahrheit.... Nun gibt es aber keine einzelne oder isolierte Wahrheit. Denn es ist alles so wunderbar verkettet, dass es schlechterdings unmöglich ist, irgend einen Gegenstand in der völligen Abtrennung von anderen Gegenständen zu zeigen.... Philosophie ist also Streben nach Erkenntnis des allgemeinen Zusammenhangs, und sie strebt notwendig und ihrer Natur gemäß nach dem System, sodass sie das Ziel nur im System und zwar nur im allgemeinen System erreicht."

${ }^{31}$ Schelling, Grundlegung, 119: "Die Philosophie ist daher wesentlich System. Denn nichts ist für sich wahr, sondern alles nur im Zusammenhang des Ganzen." The latter idea is consonant of course with the most renowned quotation from the preface to Hegel's Phänomenologie des Geistes: "Das Wahre ist das Ganze."

${ }^{32}$ Paul Klukhohn, "Voraussetzungen und Verlauf der romantischen Bewegung," in Romantik: Ein Zyklus Tübinger Vorlesungen, ed. Theodor Steinbüchel (Tübingen and Stuttgart: Rainer Wunderlich Verlag Hermann Leins, 1948), 11-26, at 26. 
itself. Critical analysis was to be accepted, but in order to render synthesis possible. ${ }^{33}$

When one puts "life" and "system" together, one almost automatically arrives at the concept (and metaphor) of organism, which unmistakably occurred in both Schelling and the Tübingen School. ${ }^{34}$ Typical of Romanticism is its organic metaphysics and worldview as well as the sweeping conviction that this implied an entirely different way of looking at things: "They [the Romantics] belonged to a new age, one repelled by the idea of mechanism as a model for order, turning instead to organism and the reconciliation of diversity in 'purposive' development." 35 This statement aptly applies to Romantic theologians and the way they looked at the cult and worship of Christians and integrated them in their theologizing.

\section{Organism in Romantic Intellectuals' Dealings with the Liturgy}

The dominance of the organic metaphor and the seeking of vital connections definitely ran through the Catholic Tübingen theologians' dealings with liturgy and sacraments, both explicitly and at a more hidden level. Liturgy and sacraments are the privileged expressions of the vitality of tradition and are connected with every dimension of people's faith and church commitment. Therefore, they cannot but be of primary importance for theologians. I will again look consecutively at Drey, Hirscher, and Staudenmaier.

\section{Drey: The Intrinsic Connection of Doctrine and Cult}

Drey developed a model for theology based on a reflection about the threefold nature of faith and church: "As the condition for its emergence, [the church] must have a common religious conviction determined by a confession ... ; as the condition for its goal, it must have a common cult determined by its liturgy; [and] as the condition for its existence in time and space, it must have a constitution determined by organic forms." 36 The

${ }^{33}$ Bernard M. G. Reardon, Religion in the Age of Romanticism: Studies in Early NineteenthCentury Thought (Cambridge: Cambridge University Press, 1985), 19. Cf. also Dupré, The Quest of the Absolute, $276 \mathrm{ff}$.

${ }^{34}$ Wilhelm Maurer, "Der Organismusgedanke bei Schelling und in der Theologie der Katholischen Tübinger Schule," Kerygma und Dogma 8 (1962): 202-16.

${ }^{35}$ Reardon, Religion in the Age of Romanticism, 21.

${ }^{36}$ Drey, Kurze Einleitung, 143: "Sie [die Kirche] muß haben als Bedingung ihres Entstehens eine gemeinsame religiöse Ueberzeugung bestimmt durch ein Symbol ... ; sie muß haben als Bedingung ihres Zweckes einen gemeinsamen Cultus bestimmt durch ihre Liturgie; sie muß haben als Bedingung ihres Bestehens in Zeit und Raum ihre 
condition for the existence of the church, says Drey, is a belief content, or creed. In order to maintain itself in the world and history, it must have a visible structure. Most interesting, however, is Drey's depiction of the liturgy, or common cult, as the condition for the church's aspirations. In other words, the liturgy determines the church's "agenda": the liturgy is what the church ought to do and be. And it can only do it on the basis of a common understanding of things (doctrine, or belief content) and within a visible form of organization (discipline, or constitution).

Furthermore, Drey understood that the links between doctrine and cult are intrinsic, and hence cannot be separated. He did not use the vocabulary of lex orandi and lex credendi, but it is evident that this is what he means: the liturgy itself expresses faith content in its own way, which is irreducible to the common epistemic-cognitive discourse of dogmatics. Drey uses the concepts of objectivity and subjectivity: what dogmatics pronounces as objective facts is subjectively appropriated in the mood (Gemüth) of the faithful. ${ }^{37}$ This was, however, not a downplaying of liturgy. To the contrary, it meant that the act of faith is not completed if there is not both a fides qua creditur and a fides quae creditur, an act of assent as well as a content to interiorize. The liturgy enables this interiorization, paradoxically by being itself the exterior expression of invisible truths of faith.

These considerations convinced Drey that the age-old division between sacramental theology and liturgical studies must be overcome. Just as scholasticism had alienated the symbol of faith (he meant the creed) in the realm of dogmatics, and as a casuistic approach had estranged the mystical life in moral theology, so the theology of the sacraments no longer had a genuine relationship with real liturgy. This division had been justified by the scholastic categorization of the essential and accidental characteristics of the sacrament. Drey passionately pleads for the reintegration of both perspectives: "Only the science that provides a complete theory of the Christian cult as idea, the essence of liturgics, and that is able to present everything non-essential to it as nevertheless in relation to its essence" can pass the test for him. ${ }^{38}$ Such a theory will even have to take into account the contingencies of history.

Verfassung bestimmt durch organische Formen." There exists an English translation of Drey's work (Brief Introduction to the Study of Theology: With Reference to the Scientific Standpoint and the Catholic System, trans. Michael J. Himes [Notre Dame, IN: University of Notre Dame Press, 1994]). However, it does not use Seckler's 2007 edition as the source text, and it typically renders the concept Verfassung as "polity." I prefer "constitution" (or, in other contexts, "discipline").

37 Drey, Kurze Einleitung, 144.

${ }^{38}$ Ibid., 148: "Allein die Wissenschaft die eine vollständige Theorie des christlichen Cultus als Idee aufstellt, die Natur der Liturgik, die alles Außerwesentliche desselben schlechterdings nur in Beziehung auf sein Wesentliches darstellen kann." 


\section{Hirscher: The Importance of Bodily Communion}

In Hirscher's dealings with the Eucharist especially one can discern similar concerns. Like Drey, Hirscher wanted to achieve a better balance between the objective and the subjective aspects of faith and liturgy. Therefore, he found it necessary to emphasize the importance of the right disposition of the faithful in receiving communion. He by no means denied the doctrine of the ex opere operato efficiency of sacramental economy, but he deliberately put the ex opere operantis dimension alongside it. Hirscher, moreover, made a case for reciprocity in what he called the "sacramental act," in which there is both a human and a divine share. The part of the human being cannot consist in being only a passive recipient; in addition to receptivity (Empfänglichkeit) as a basic attitude there must be actual reception (Aufnahme) as well. In other words, it is of paramount importance that the human person is fully involved in the act of faith as it is mediated through sacraments and liturgy.

Aware of ancient Christian practices, ${ }^{39}$ Hirscher realized that the catechetical program and formation of youth should culminate in the celebration of the "sacrament of the altar" and the worthy reception of communion, for one encounters there the living Son of God. The catechist should instruct children in such a way that they appear before the altar:

as if [they appeared] before Jesus Christ [himself]; that they encounter Him as if on Golgotha; that they see in their minds the Living and loving one, their Lord and sovereign, their Savior and Holy One, their Vivificator and judge; that they approach Him with the firmest faith, the innermost love and acquiescence, the highest humility and joyfulness, [as well as with] comforted hope and confidence; that they receive Him and all truth and blessing of the gospel in Him, and that they are joyfully aware that they ought to receive Him so. ${ }^{40}$

${ }^{39}$ Although we cannot develop this here in detail, it must be mentioned that the Tübingen School also anticipated twentieth-century theological evolutions like the Liturgical Movement and the nouvelle théologie inasmuch as its representatives employed a method of ressourcement and found much inspiration for their theologies in the writings and prayerful thought-world of the Church Fathers. For more background on these important dimensions, see Goyvaerts, "A Romantic Theology."

${ }^{40}$ Hirscher, Katechetik, 604-5: “... als vor Jesus Christus; daß sie Ihm entgegentreten, wie auf Golgotha; daß sie im Geiste den Lebenden und liebenden, ihren Herrn und Fürsten, ihren Erlöser und Heiliger, ihren Lebendigmacher und Richter vor sich sehen; daß sie Ihm mit dem festesten Glauben, der innigsten Liebe und Ergebung, der höchsten Demuth und Freudigkeit, der getrostesten Hoffnung und Zuversicht nahen; daß sie Ihn, und alle Wahrheit und Segnung des Evangeliums in Ihm empfangen, und empfangen zu haben freudig gewiß sind." 
In other words, the youth should feel engaged and well prepared for the encounter with their Redeemer. An attitude of delightful expectation and due reverence is only appropriate. What strikes one in this passage, however, is the vividness of the language with which the encounter is described.

One can apply the same insight to the passages where Hirscher focuses on eucharistic communion in a very lively manner. One can observe how he imagined the unification of the mystery of Christ and the individual believer in a concrete way-that is, that he did not overlook the body and the senses. Because Jesus Christ is the source of all truth and grace, Hirscher argues, it is he who offers himself in the meal in which the faithful are taken up. Significantly, he uses verb forms in the first person plural here:

[We are] taken up as the food of our spiritual life, just as we receive bread and wine as nourishment of the bodily [life]; [we are] taken up so deeply and so intimately, in such a way that the whole spiritual dimension of our human existence is permeated, just as bodily food is eaten and, nourishing, permeates the bodily dimension of our human existence. ${ }^{41}$

This emphasis on the bodily aspect of communion as an indispensable liturgical reality is closely connected to the theological realism that permeates Hirscher's understanding of Christ's real presence in the Eucharist. Jesus Christ is present (gegenwärtig) with a view to the sacramental unification with the faithful. ${ }^{42}$ Moreover, his presence and act of unification with the faithful are organic and the condition for the organic unity of the faithful among themselves. The Eucharist is "the visible presentation of the organic union of Jesus Christ the Head with his faithful as the members; as well as the visible presentation of the organic union of the faithful among themselves, under him the Head, in one and the same Holy Spirit." 43

\section{Staudenmaier and the Sacrament of Reunification}

Staudenmaier would no doubt have subscribed to the above passage. According to him, the highest goal of the Christian religion is union with Christ, which is expressed in the most outstanding way possible in the

${ }^{41}$ Hirscher, Katechetik, 590: "aufgenommen werden somit als die Speise unseres geistigen Lebens, gleichwie wir Brod und Wein als die Nahrung des leiblichen empfangen; aufgenommen werden so tief und innig, so ganz den geistigen Menschen durchdringend, als die leibliche Speise genossen wird, und den leiblichen Menschen nährend durchdringt."

42 Ibid., 594.

${ }^{43}$ Hirscher, Die christliche Moral, 2:112: "die sichtbare Darstellung der organischen Einheit Jesu Christi des Hauptes mit seinen Gläubigen als den Gliederen; desgleichen als sichtbare Darstellung der organischen Einheit der Gläubigen untereinander, unter Ihm dem Haupte, in Einem und demselben heiligen Geist." 
celebration of the Eucharist: "The idea, which becomes real and objective in the Eucharist, is precisely the idea of the highest, most intimate, and most vivid unification of the human being with God, the idea of God's becoming-one with and through the God-man." ${ }^{44}$ Just like Hirscher, Staudenmaier underscores that this is not simply a spiritual reality but one with close ties to physical reality. It is a corporeal action of a person, with profound spiritual significance: "Here the most intimate connection of bodily life with that from which it lives has been shown. This relationship makes itself also known-but only in a higher sense-in the spiritual life of the human person, who in the Eucharist enters into a lively connection with Christ." 45 Again it is striking how much emphasis is put on vitality and connection.

This connection with the real life of people is important for Staudenmaier, because reunification and reconciliation with God cannot be imagined otherwise. Liturgy is the complex of actions that constitutes the "real life" of the Christian religion: "In cult, religion celebrates its highest moments, for cult is the action, the activity of religion proper, and therefore its real life; through cult one celebrates the reconciliation and unification of humanity with God." 46 The sacraments embody God's sacramental grace and communicate it to humanity by means of a variety of ritual actions. This communication, however, is a dynamic process between different partners instead of the delivery of a product. It is not the case that God's gift is ill adapted to the existential situation of the human being; if it were, he would not have given himself in the forms of food and drink.

Two other dimensions of Staudenmaier's theology of the Eucharist must be mentioned, because otherwise the picture would be deficient. First, he explicates the interpretation of the Eucharist as a mystery of love, where the vertical and the horizontal dimensions meet. Second, Staudenmaier sees the Eucharist as constitutive of the church, thereby anticipating much of Henri de Lubac's double theological intuition that the Eucharist "makes" the

${ }^{44}$ Staudenmaier, Encyclopädie, 438: "Die Idee, die im Abendmahle wirklich und objektiv wird, ist eben die Idee der höchsten, innigsten und lebendigsten Vereinigung des Menschen mit Gott, die Idee des Einswerdens Gottes mit und durch den Gottmenschen."

45 Staudenmaier, Encyclopädie (2nd ed., 1840), 768: "Es ist hier der innerste Zusammenhang des leiblichen Lebens mit dem, woraus es lebt, angezeigt. Dieses Verhältnis macht sich nun auch, nur in einem höhern Sinne, geltend im geistigen Leben des Menschen, der mit Christus im Abendmahl in lebensvolle Verbindung tritt."

${ }^{46}$ Staudenmaier, Der Geist des Christenthums, 1:256: "Im Cultus feiert die Religion ihre höchsten Momente, denn der Cult ist der Act, die Handlung der Religion selbst, hiermit ihr wirkliches Leben; durch den Cult wird die Versöhnung und Vereinigung des Menschen mit Gott gefeiert." 
church as much as the church "makes" the Eucharist. ${ }^{47}$ Staudenmaier puts it this way:

The love, which is here [i.e., in the Eucharist] love for God and Christ in us and which becomes always more lively, is also love for the brothers [or neighbors, as one would say today]. Therefore, the Eucharist is the great sacrament of unification. The church, as community in love, maintains to this sacrament the closest connection, because the church itself as the great lively unification of all with God and one another borrows [its very being] from it. ${ }^{48}$

Interestingly, Staudenmaier uses the famous Pauline image of 1 Corinthians 12:12 ff. to further substantiate the same point. The Eucharist constitutes the unity of the church; the church vitally integrates each and every member in its very being:

Through this [Eucharistic] unity everyone becomes an agile and vivacious member, and thus one can understand how the Eucharist is that sacrament which has a truly particular and efficacious relation to the church, because in it she sees and establishes herself always anew and because [through it] she realizes the eternal idea underlying her and presents this in all objectivity-which is moreover the reason that this sacrament can only be truly known in the church and that the doctrine of the Eucharist constitutes an essential part of the doctrine of the church. ${ }^{49}$

${ }^{47}$ Henri de Lubac, The Splendour of the Church, trans. Michael Mason (London: Sheed and Ward, 1956), secs. 3 and 4 of chap. 4. For a commentary, see also Paul McPartlan, The Eucharist Makes the Church: Henri de Lubac and John Zizioulas in Dialogue (Edinburgh: T\&T Clark, 1993).

${ }^{48}$ Staudenmaier, Encyclopädie, 428: "Die Liebe aber, die hier [i.e., in the Eucharist] zu Gott und Christus in uns ist und immer lebendiger wird, ist auch eine Liebe zu den Brüdern. Deswegen ist das Abendmahl das große Sakrament der Vereinigung, und die Kirche als Gemeinschaft in der Liebe steht zu ihm in der allerengsten Verbindung, weil eben die Kirche selbst als die große lebendige Vereinigung Aller mit Gott und unter einander aus ihm nimmt." See in this context Sam Goyvaerts, "Das große Sakrament der Vereinigung.' Franz Anton Staudenmaier's Eucharistic Theology," in Joris Geldhof, Daniel Minch, and Trevor Maine, eds., Approaching the Threshold of Mystery: Liturgical Worlds and Theological Spaces, Theologie der Liturgie 10 (Regensburg: Friedrich Pustet, 2015) 89-97.

${ }^{49}$ Staudenmaier, Encyclopädie, 440: "Durch diese [i.e., eucharistische] Einheit wird Jeder am Leibe Christi ein regsames lebendiges Glied, und eben dadurch ist zu begreifen, wie das Abendmahl jenes Sakrament sei, das zur Kirche ein ganz besonderes rückwirkendes Verhältnis hat, weil sie in ihm sich selbst stets aufs neue schaut und erbaut, und die ihr zu Grund liegende ewige Idee verwirklichet und in der Objectivität darstellt, weßhalb dieses Sakrament auch nur in der Kirche wahrhaft erkannt werden 
Clearly, for Staudenmaier, the ecclesial and the sacramental dimensions of the idea of the Body of Christ are intimately intertwined, which is at the same time the reason he says that one cannot develop any ecclesiology without the Eucharist, and, conversely, why any theology of the Eucharist must include a reflection on the church.

What is common in all these reflections on liturgy and Eucharist is a typically Romantic organic mode and model of thinking. Drey wanted to reestablish lively connections among church discipline, doctrine, and ritual expressions of the faith. The basic inspiration for that was the conviction that the three munera of Christ, the risen and the living One, can and should be set forth in the church's life of faith. Drey also argued that because of these lively connections, the outline of the study of theology and theologizing itself had to be renewed. Hirscher imagined eucharistic communion as an act of reception in which Christ and the church are organically interrelated, not only spiritually, but also in the deep corporeal dimensions of human existence. Staudenmaier continued in the same line. He stressed above all else the soteriological importance and significance of humanity's-and each individual person's-reconciliation with God through church and Eucharist, whereby the work of reconnecting must be understood in an organic fashion.

Interestingly, this organic way of imagining things allowed for a strong theory of liturgy and sacraments that went beyond the perils of both a strict objectivism and a loose subjectivism. Both from a historical perspective and within the contours of fundamental and systematic theological reflection, scholars of a much more recent era have developed similar attempts to overcome the divide: liturgy is neither the merely objective and traditional deposit of faith, passed on through unchangeable formulas, prescriptions and ceremonies, nor is it the extension of one's personal feelings and impressions, or the always-contingent ritual expression of what a community thinks. ${ }^{50}$

\section{The Organic in the Origins of Liturgical Theology}

Without a doubt, the Tübingen School's Romantic approach to liturgy and sacraments set a lasting example. Whether or not the line continues in a

kann, wie denn die Lehre vom Abendmahle ein wesentlicher Bestandteil der Lehre von der Kirche ist."

${ }^{50}$ See, e.g., Arnold Angenendt, Liturgik und Historik: Gab es eine organische LiturgieEntwicklung? Questiones Disputatae 189 (Freiburg: Herder, 2001); Louis-Marie Chauvet, The Sacraments: The Word of God at the Mercy of the Body, trans. Madeleine Beaumont (Collegeville, MN: Liturgical Press, 2001), esp. the "Overture." 
direct way, and whether that continuity is strong and intrinsic or rather feeble and the result of mere contingencies, cannot be the subject of my investigations here. But it is at least notable that the origins of liturgical theology in the early twentieth century can be rightly called Romantic, at least from a philosophical and fundamental-theological point of view, because it operates within an obviously organic paradigm of thought. On the one hand, it aims at a vital and dynamic understanding of the phenomena under consideration, while, on the other hand, it aspires to proceed synthetically and systematically, that is, definitely not rigidly, purely analytically, or mechanically.

I will show this utterly Romantic outline of the "arche" of liturgical theology by briefly elaborating three representative illustrations. First, I refer to the seminal study by Dom Lambert Beauduin (1873-1960), La piété de l'église, which was not literally but aptly translated by Dom Virgil Michel (18881938) under the title Liturgy: The Life of the Church. ${ }^{51}$ Second, I discuss Romano Guardini (1885-1968) and his idea of the necessity of a "systematic" approach to liturgy. Third, I present a driving intuition of Pius Parsch (18841954), the famous Augustinian canon from the Austrian monastery of Klosterneuburg, who is widely credited for his initiatives in pastoral liturgy. Whereas the first example deals with the phenomenon of the liturgy itself, the second focuses rather on the corresponding theological, or academic, discipline. The third adds another, yet equally indispensable, dimension of the Liturgical Movement, namely, the untiring efforts to bring not only the people to the liturgy, but also the liturgy to the people. The point is, however, that this more practical tenet is also, on closer inspection, deeply Romantic and organic in the senses we have described here.

\section{Lambert Beauduin and the Body of Christ Metaphor}

When one reads Beauduin's fine reflections on the liturgy, it is striking how dominant the Pauline image of the one body with its many members is, and how passionately Beauduin emphasizes the liveliness of the liturgy: "The liturgy lives and unfolds itself also today and, because universal, is of the twentieth century as well as of the first. It lives and follows the dogmatic and organic developments of the Church herself." 52 The liturgy and the church are almost personified, which is theologically legitimate because they are both in a direct connection with the living and the Risen One.

The Pauline metaphor is used as well to express the links existing between the heavenly and earthly liturgy:

51 Lambert Beauduin, Liturgy: The Life of the Church, trans. Virgil Michel (Collegeville, MN: Liturgical Press, 1926). The original French version dates from 1914.

52 Beauduin, Liturgy, 36. 
Between the Church of heaven and the Church of the earth there exists an intimate union which shall one day become perfect. This union manifests, nourishes, and develops itself by a common participation in spiritual goods, by communications of merit and individual goods, by a continual exchange of prayers offered to God for the welfare and spiritual progress of each member and for the increasing prosperity of the entire body. The Catholic is therefore, by definition, a member of a visible organism. ${ }^{53}$

This idea of a visible organism runs through the entire work; it appears already on the very first page, ${ }^{54}$ where the Belgian monk sets out the fundamental principles of the liturgy. According to him, these principles basically consist in the sanctifying grace of Christ being mediated and communicated by the church.

What is even more striking is that the concept that was to become the central focus of the Liturgical Movement, active participation, finds its original anchor in the same atmosphere of Romantic thinking. Beauduin not only quotes the famous passage from Pope Pius X's motu proprio Tra le sollecitudini, but also says this: "Active participation in the liturgical life of the Church is a capital factor in the supernatural life of the Christian. We found the evidence thereof in the organic life of the Church." 55 The anchoring of the concept of active participation in a Romantic and organic understanding of the life of the church brings along not only the necessity of a practical and pastoral strategy, which Beauduin looked after as no one else, but also the invitation to think more deeply about what participation is. Beyond the importance of the vernacular, "the members must have the same life as the body of which they are parts.... This is a necessary condition of order, of harmony, of peace. As a true member, the Catholic ought to adapt himself, unite himself as intimately as possible, to the mystical body of Christ." ${ }^{56}$ In other words, it requires not only that the institution (or hierarchy, as Beauduin would call it) take measures to better facilitate active participation of all the faithful, but also that the individual faithful open themselves to receive the sanctifying grace of the Lord. Moreover, these intertwining operations of body and members should be imagined as a natural and living process instead of a mechanical program.

When evaluating the many merits and historical vicissitudes of the Liturgical Movement, Louis Bouyer spoke about Dom Lambert Beauduin in very positive terms; in him, he said, one "should revere one of the most

\footnotetext{
53 Ibid., 23 (emphasis in the original).

${ }^{54}$ Ibid., 9.

55 Ibid., 17 (my emphasis).

${ }^{56}$ Ibid., 33.
} 
simple and unpretentious yet one of the greatest figures of the Church in the twentieth century." 57 The basic reason for this is precisely his deep intuitions about the nature of liturgy and, in particular, its vital and vivid nature. According to Bouyer, Beauduin "realized that the liturgy itself... is meant to be the well-spring of spiritual vitality and to provide the framework for Christian living, not only for individuals, not only for some Christians, but for the whole Christian people in the Church." ${ }_{58}$ This comment is almost similar to holding that Beauduin was a true Romantic thinker indeed, though definitely not of a dreamy and idealist kind. To the contrary, Bouyer correctly sees in the "Belgian liturgical movement" as embodied by Beauduin a "true realism" that "was ruled and inspired by a wide and deep devotion to the Church, the actual hierarchical and collective Church of today, acknowledged as the living body of Christ." 59

\section{Romano Guardini's Case for a Systematic Approach to Liturgy}

Regarding Guardini, the first reference should of course be his groundbreaking 1918 essay The Spirit of the Liturgy. ${ }^{60}$ Already on the very first page Guardini draws the parallel between a living body and the liturgy: "Just as the life of the body droops and is stunted when the conditions of its growth are not observed, so it is with spiritual and religious life-it sickens, losing its vigor, strength and unity. This is even more true where the regular spiritual life of a corporate body is concerned." ${ }^{61}$ Obviously, Guardini is talking here about the church and the celebration of the sacraments, for "the Catholic liturgy is the supreme example of an objectively established rule of spiritual life." 62 In other words, the liturgy is fundamentally the "church at prayer," ecclesia orans, and it was definitely not a coincidence that this phrase was chosen as the title of the series in which Guardini's book appeared as the first volume. ${ }^{63}$

Like Beauduin and the Tübingen School before him, Guardini relies heavily on the Pauline metaphor of the body and its members when he imagines the church and its primal activity of prayer. "The faithful are actively united by a vital and fundamental principle common to them all. That

${ }^{57}$ Louis Bouyer, Life and Liturgy, 4th ed. (London: Sheed and Ward, 1978), 59.

${ }^{58}$ Ibid., 59-60.

59 Ibid., 63.

6o Romano Guardini, The Spirit of the Liturgy, trans. Ada Lane (1935; New York: Crossroad, 1998).

${ }^{61}$ Ibid., 17.

62 Ibid., 18.

63 This series was founded by Dom Ildefons Herwegen (1874-1946), abbot of Maria Laach, where Dom Odo Casel (1886-1948) was one of the monks. 
principle is Christ Himself; His life is ours; we are incorporated in Him; we are His Body, Corpus Christi mysticum." 64 The image of the Body of Christ moreover enables Guardini to stress that the community of the church does not coincide with the people who have assembled for worship at a certain time and in a given space: "The liturgy is not celebrated by the individual, but by the body of the faithful. This is not composed merely of the persons who may be present in church; it is not the assembled congregation"65_an insight that was recently repeated in similar terms by Walter Kasper when he made a case for a "new liturgical culture." Kasper holds that the celebrating church is never only the congregatio fidelium but always also the communio sanctorum. ${ }^{66}$

Yet if all of this is true, it will come as no surprise that one needs a particular approach to liturgy in order to do justice to its nature. Guardini fundamentally assumes "daß die Liturgie etwas verbindliches ist" (that the liturgy is something binding). ${ }^{67}$ This is a subtle pun in German, inasmuch as the word verbindlich evokes both the idea of connecting and that of obliging. Therefore, Guardini maintains, liturgical studies must take into account not only the fact that liturgy "is" or "lives" but also that it "applies" in the sense of "remaining in force" (gelten). ${ }^{68}$ In other words, it is important to hold onto a thoroughly realistic view on liturgy. "I understand this as the attitude which sees the heart of the liturgy not in its didactic-pedagogical content but in the real, mystic events and essences, which it embraces." ${ }^{69}$ Because of this real-mystical shape and content of the liturgy, liturgical studies cannot but be theological, or theology, par excellence: "It's all about theology, i.e. doctrines about the supernatural revelation and life-communication.... Therefore, the work of liturgical theology primarily deals with the

64 Guardini, The Spirit of the Liturgy, 37.

65 Ibid., 36.

${ }^{66}$ Walter Kasper, Aspekte einer Theologie der Liturgie: Liturgie angesichts der Krise der Moderne-für eine neue liturgische Kultur, in Kasper, Die Liturgie der Kirche, Gesammelte Schriften (Freiburg: Herder, 2010), 10:15-83, esp. 58-63.

67 Romano Guardini, "Ueber die systematische Methode in der Liturgiewissenschaft," Jahrbuch für Liturgiewissenschaft 1 (1921): 97-108, at 98.

${ }^{68}$ In this context, Guardini refers to the influential manual by Thalhofer-Eisenhofer, to some essays by Festugière and Callewaert, but also to Beauduin's La piété de l'église. (This is just one example of how international the early Liturgical Movement was.) Moreover, in one of the other footnotes of this article, Guardini inserted a reference to Staudenmaier's Geist des Christenthums.

69 Guardini, "Ueber die systematische Methode," 100: "Ich verstehe darunter jene Einstellung, welche den Schwerpunkt der Liturgie nicht in ihrem didaktischpädagogischen Gehalt, sondern in den realen mystischen Vorgängen und Wesenheiten erblickt, die sie umschließt." 
supernatural truth and order of life which the church has decisively mediated."70 Methodologically, this implies nothing else but an encompassing organic approach:

Research ought to proceed organically, i.e., operations are led by the assumption that liturgy is not an accumulation of individual pieces without coherence. Rather [it is the case that] a powerful principle of life shaped for itself a unified expression through an incredible number of factual and spatio-temporal particularities. ${ }^{71}$

In other words, it is necessary to always take into account the entirety of the liturgy ("die umfassende Gesamteinheit"), even if one scrutinizes little parts or historical details of it. Sharp divisions according to an either-or principle are to be avoided in order to enable a more fruitful both-and approach. Guardini, who gave a talk about the essence of Romanticism later in his career, ${ }^{72}$ concludes his reflections about the systematic method to be employed in liturgical studies with a strong statement about the goal and scope of the field. Liturgical theology "aims to bring out the doctrinal content of the life of cult, not, however, with a view to developing a system of faith or moral code, but with a view to grasping the lively reality of ecclesial worship from the most different angles. It is the methodological investigation of the real church in its life of prayer."73

\section{Pius Parsch and Pastoral Liturgy as Organic Acting}

One of the major goals of Pius Parsch's life and ministry was to get ordinary people in contact with the church's liturgy in an authentic and

${ }^{70}$ Guardini, "Ueber die systematische Methode," 104: "Es handelt sich um Theologie, d. h. um Lehre von der übernatürlichen Offenbarung und Lebensmitteilung.... So gilt die Arbeit der liturgischen Theologie zunächst der von der Kirche maßgebend vermittelten übernatürlichen Wahrheit und Lebensordnung."

${ }^{71}$ Guardini, "Ueber die systematische Methode," 105 (my emphasis): "Und zwar muß die Forschung dabei organisch vorgehen, d. h. das Verfahren ist von der ... Voraussetzung geleitet, daß die Liturgie keine Anhäufung zusammenhangloser Einzelstücke ist. Vielmehr hat ein machtvolles Lebensprinzip sich hier seinen bei höchster Mannigfaltigkeit der sachlichen und zeit-örtlichen Eigenheiten doch ganz einheitlichen Ausdruck geschaffen."

72 Romano Guardini, "Erscheinen und Wesen der Romantik," in Steinbüchel, Romantik, 235-49.

${ }^{73}$ Guardini, "Ueber die systematische Methode," 108: “will ... den Lehrgehalt des Kultlebens herausholen, aber nicht um ein System der Glaubens oder Sittenlehre aufzustellen, sondern um die lebendige Wirklichkeit des kirchlichen Gottesdienstes von den verschiedensten Seiten her zu erfassen. Sie ist die methodische Erforschung der wirklichen Kirche in ihrem Gebetsleben." 
substantial way. In doing that through a great variety of initiatives, Parsch obviously shared much with other central figures of the early twentieth-century Liturgical Movement, such as Beauduin, Guardini, and Odo Casel. Parsch especially devoted a lot of his energy to "truly" liturgical preaching and left a work on that topic unfinished when he unexpectedly died in the mid-1950s. However, ten exemplary homilies by him, all centering on the symbol of the mystical Body of Christ, have been translated and published in English. Parsch lucidly summarizes the immense potential of the Body of Christ image as follows:

An... advantage of this great doctrine is that it enables us to see our religion as a whole-as a unity. Some forty years ago many people looked at Christianity only bit by bit-and often the bits they saw most clearly were not the most important bits. But here we are brought right into the center of our faith, and everything of prime importance is made to stand out clearly and in its context: Christ, the Church, the Holy Ghost, grace, the Eucharist, the sacraments, the entire liturgy, and also sin. All these can be clearly seen as a unity with their due proportions and interconnections when explained in terms of the Mystical Body doctrine. ${ }^{74}$

Clearly, for Parsch, the Pauline metaphor performs an important function of keeping things together. In addition, it serves as a criterion for sifting through the important parts and the details and for distinguishing between the core and the margins. So he continues:

But best of all this doctrine helps us to know the very essence of the three main components of the Mystical Body: Christ as head of the Church, the fount of grace who is in permanent union with the body and the members; the Church as a grace-filled organism rather than a mere association; and Christians as enjoying a wondrous dignity because they are members of the Church, grace-filled members of Christ. And so the simile of the Mystical Body gives us an insight into our religion which can hardly be attained in any other way. ${ }^{75}$

To be sure, when Parsch speaks about "our religion" in this context, he means the celebration of the liturgy, including its profound sacramental principle, which cannot but be understood along the same Romantic lines of synthesis and liveliness. This becomes evident when he pushes further the idea that the church is (like) a body, and thus uses obvious eucharistic imagery:

\footnotetext{
${ }^{74}$ Pius Parsch, We Are Christ's Body, ed. and trans. Clifford Howell (Notre Dame, IN: Fides Publishers, 1962), 14.

75 Ibid., 14-15 (my emphasis).
} 
We can discern in the Church (a) singleness of body with plurality of members; (b) a life which is that of the body as a whole; (c) union with a head; (d) union among the members; (e) a soul which animates the body; (f) functions performed by the body; (g) conditions required for continued life, especially nourishment. ${ }^{76}$

That Christ himself is the "bread of life" and that the liturgy of the Eucharist is, above everything else, to be seen as a "mysterial" reenactment of the entire redemptive mystery is emphasized as well in Parsch's pastoral-liturgical handbook on the Eucharist:

Christ appears to us in the Mass in the work of His redemption not only to be present among us, to comfort us, and to teach us, but also to unfold the divine life and preserve it in us. Therefore this memorial rite is at the same time a banquet: it is the bread of heaven, the bread of life, the meal of sacrifice. It is the bread that unites us intimately and inseparably with the source of all life, with Christ, who nourishes the life of grace within us. ${ }^{77}$

In other words, the Eucharist in particular-and the liturgy in general-must be understood in no other than organic terms.

Therefore, any initiative in pastoral ministry and liturgical catechesis must be grafted onto this liturgical-sacramental spine. So much is clear from the way in which Parsch concludes his handbook, when he embarks on a discussion of the mystery of the Eucharist. He underscores that the efforts to interiorize the meaning of the Eucharist must always have recourse to the wholeand thus one can never do justice to it by simply analyzing it as if one cut it into small pieces. A genetic explanation of the individual components of the Mass, as would be developed later by Josef Andreas Jungmann (1889-1975), makes a lot of sense to Parsch, but the preference is that it must be done with due reference to their inner coherence. Yet, says Parsch, "another method for evaluating a Mass formula is to consider the Mass as a whole, and to follow the course and development of its dramatic action"78 - in other words, to treat it as an organic enactment. When one undertakes this in any concrete pastoral-liturgical setting, one has to be reminded of three points: "(1) the variable parts of the Mass are the vesture in which the mystery of the sacrifice is clothed for the day; (2) [one] must endeavor to resuscitate the Mass from what might be called its petrified state to the warmth and life of the congregational

76 Ibid., 29.

77 Pius Parsch, The Liturgy of the Mass, trans. Frederic C. Eckhoff (St. Louis and London: Herder, 1947), 14 (my emphasis).

78 Ibid., 340. 
celebration of ancient times; (3) the Mass must be conceived as a drama and explained as such."79

\section{On the Future of the Connection between Romanticism and Liturgical Theology}

Although there is still much more research to be done (among other things, on the precise historical dependency of [early] liturgical theologians on Romanticism and the import of other representatives than the ones discussed), it is fair to conclude that there is significant correspondence between German Romanticism and liturgical theology. Moreover, this correspondence seems to affect both content and method, or matter and form, whereby these poles are, indeed, organically interwoven. The insights of Romantic intellectuals and of representatives of the early Liturgical Movement about what liturgy is, fundamentally, as well as their proposals to approach and understand it in the most appropriate way, display a substantial amount of overlap.

In addition, it may be fair to conclude that liturgical theology is intrinsically Romantic, because it tries to understand liturgy both systematically and as a living reality. This double emphasis can be interpreted as the most promising way to overcome the pitfalls of objectivism and subjectivism. Whereas the former position risks losing the connection with life and may end up in traditionalism, the latter position does connect with real life but might forget about the fact that the liturgy is not the product of collective desires but is always an anterior reality. In other words, organic thinking saves a robust reality claim and thereby avoids the dangers of both estrangement and illusion. Could one, consequently, go one step further and assert that contemporary liturgical theology ought to be Romantic? ${ }^{80}$

If the answer to that question is, or tends to be, positive, I think that the following thoughts are implied, or at least worth considering. It needs to be stressed, however, that these reflections are by no means meant as a kind of critical diagnosis. They contain no judgment about what is not, or not sufficiently, done, but are intended to substantiate and contribute to

79 Ibid., 343-44.

${ }^{80}$ In this context it needs to be stressed that I will not engage here in a discussion about the idea of an "organic development" of the liturgy, as exemplified in the work of Alcuin Reid, The Organic Development of the Liturgy: The Principles of Liturgical Reform and Their Relation to the Twentieth-Century Liturgical Movement Prior to the Second Vatican Council (San Francisco: Saint Ignatius Press, 2005), and László Dobszay, The Restoration and Organic Development of the Roman Rite (London and New York: T\&T Clark, 2010). It strikes one, however, how little fundamental theological and philosophical reflection there is on the notion itself of organism in these works. 
fundamental directions that the research of (some) contemporary liturgical and sacramental theologians has taken.

First, the permeability of being must be explored with renewed interest and vigor, and this exploration might involve a restored confidence in metaphysics-albeit, clearly not in the classical sense. ${ }^{81}$ If the connections between visible and invisible realities and between time and eternity are indeed organic (that is, if they cohere in a systematic way and are at the same time vivid), it means that the scope of liturgical theology cannot be limited to the physically observable, and that its origin cannot be mere experience. Maybe more so than is the case now, liturgical theology should then give evidence of "an essentially positive worldview that, moving beyond the limits of a rational culture, inspire[s] a relentless and obviously impossible drive to overcome the finitude of the human condition," 82 no matter how paradoxical this enterprise may seem. Traces of the absolute, the infinite, and the transcendent but speaking God must be sought and related with inner-worldly developments and experiences. Liturgical theology is called to be (at) the heart of the reality of faith and, as Dom Lambert Beauduin so eloquently suggested, should operate with "an exuberant enthusiasm for the supernatural life." 83

Second, it seems preferable that researchers in the field of liturgical theology continue to show a great amount of daring in the methods they use. Such a widening of the methodological horizons fits wonderfully well with the positions that many liturgical scholars have taken ever since it was broadly accepted that textual material and philological approaches cannot be the only ways to advance in scholarship and insight. ${ }^{84}$ To think organically means not only to start from reality itself, in this case the actual celebration of liturgy and sacraments, but also to take into account and to do justice to human existence and human personhood as a whole. Therefore, the access to the phenomenon under consideration does not happen exclusively through openings created by the cognitive and intellectual capacities with which human beings are equipped. A narrow focus on reason was precisely the occasion for the Romantic impulse not to deny or neglect the importance of a rational grasp, but to explore other channels of comprehending and

81 In this context a reference to Chauvet's groundbreaking 1987 study Symbole et sacrament is indispensable, of course. Louis-Marie Chauvet, Symbol and Sacrament: A Sacramental Reinterpretation of Christian Existence, trans. Patrick Madigan and Madeleine Beaumont (Collegeville, MN: Liturgical Press, 1995).

82 Dupré, The Quest of the Absolute, 4.

83 Beauduin, Liturgy, 28.

84 Think, for example, of Lawrence Hoffman, Beyond the Text: A Holistic Approach to Liturgy (Bloomington: Indiana University Press, 1987). 
living-through. The (spiritual) senses, the body, the will-as well as the realms where desires and the passions rule-do have something important to contribute when it comes to unfolding and explaining the existential pertinence of liturgy. ${ }^{85}$ I think that the imagination in particular is well suited to play a more prominent role in contemporary liturgical-theological scholarship, not in replacement of, but in addition to, what reason can achieve. ${ }^{86}$ Furthermore, the imagination seems particularly apt to grasp the mystery of the liturgy and is therefore instrumental to building bridges between liturgical and systematic theologians. ${ }^{87}$

Third, love needs to be addressed. It may seem strange that, in spite of one quotation from Staudenmaier, love appears only at the end of this article. But that was a deliberate choice, for one would actually need a second article to develop this intuition in depth and give it the attention it deserves. Nevertheless, Charles Williams was right when he regarded love, not only the selfless agape but also sexual love, as the only essential theme of a truly Romantic theology. "The principles of Romantic Theology can be reduced to a single formula: which is, the identification of love with Jesus Christ, and of marriage with His life. This again may be reduced to a single wordImmanuel. Everything else is modification and illustration of this." ${ }^{88} \mathrm{How}$ to realize this and live accordingly, however, is by no means evident. But a liturgical perspective could probably help to solve the problem identified by Williams: "The reason for the difficulty which man experiences in realizing that Christ's sayings are the expression of Life itself, the actual life which he is living, is that, in general, first men have no acute and shapely sense of Life as a whole, and secondly, they do not imagine Life as identical in the end with Christ." 89 The liturgy and the celebration of the sacraments can generate the transformative power that is needed to renew humanity according to the ideal of divine love-on the condition that liturgical theology is understood Romantically and liturgy itself organically.

${ }^{85}$ Inspiring in this regard is an essay by Catherine Pickstock, "Sense and Sacrament," in Boersma and Levering, The Oxford Handbook of Sacramental Theology, 657-74.

${ }^{86}$ For an interpretation of the imagination in line with its Romantic potential, see Joris Geldhof, "Mirroring Truth: A Theological Appropriation of Imagination along with Speculation," Louvain Studies 36 (2012): 3-21; for an exploration of its connection with worship, see Margaret Kelleher, "Liturgy and the Christian Imagination," Worship 66 (1993): 125-48.

${ }^{87}$ See, e.g., Mediating Mysteries, Understanding Liturgies: On Bridging the Gap between Liturgy and Systematic Theology, ed. Joris Geldhof, BETL 278 (Leuven: Peeters, 2015).

${ }^{88}$ Charles Williams, Outlines of Romantic Theology, ed. Alice M. Hadfield (Berkeley: Apocryphile Press, 2005), 14.

${ }^{89}$ Ibid., 28. 